\title{
Exploring the factors that influence the career decision of STEM students at a university in South Africa
}

\author{
Ethel Ndidiamaka Abe ${ }^{*}$ id and Vitallis Chikoko
}

\begin{abstract}
Background: Science, Technology, Engineering, and Mathematics (STEM) educators and stakeholders in South Africa are interested in the ways STEM students make their career decisions because of the shortages in these critical skills. Although various factors including family, teachers, peers, and career interest have been reported as determinants of career decision-making, there is a scarcity of studies that have qualitatively explored the levels of influences of any of these factors in the South African context. The main aim of this study was to investigate the factors that influence career decision-making among STEM student majors in a South African university. By better understanding students' viewpoint on these factors, educators and policymakers can assist students in making career decisions that fit their experiences, personality, and expectations. Students in their 1st, 2nd, 3rd, and 4th year of study respectively, were invited to respond to a semi-structured questionnaire about the factors that were influential in their decision to pursue a career in STEM. A total of 203 texts (response rate: 63\%) were qualitatively analyzed utilising a hermeneutic phenomenology approach to traditional content analysis, whereby themes develop inductively from the data.

Results: We used a hermeneutic phenomenological method to traditional content analysis to examine the factors influencing participants' career decision-making. Peer interrogation, modified member verification, compact description, code-recode tactics, and assessment trails were engaged to confirm quality and rigour. Three key results emerged, namely interpersonal, intrapersonal, and career outcomes expectancy. The perceptions of STEM students of their career decision-making in the South African context are more multifaceted than reported previously. The insights could inform policies to counter skills shortages in the STEM area.

Conclusions: In this exploratory study, we gave attention to describing the various ranges of students' perceptions and experiences regarding their career decision-making. Several students reported, among other factors, that their families, personality, and expectations played influential roles in their career decision-making. Here, we discuss the meaning of interpersonal, intrapersonal, and outcome expectations with respect to career decision-making from the perspective of STEM students in a South African university.
\end{abstract}

Keywords: Career decision-making, Social cognitive career theory, Interpersonal factors, Intrapersonal factors, Career outcomes expectancy, Career interest

\footnotetext{
*Correspondence: abee@ukzn.ac.za

School of Education, University of KwaZulu-Natal, Durban, South Africa
}

\section{Springer Open}

() The Author(s). 2020 Open Access This article is licensed under a Creative Commons Attribution 4.0 International License, which permits use, sharing, adaptation, distribution and reproduction in any medium or format, as long as you give appropriate credit to the original author(s) and the source, provide a link to the Creative Commons licence, and indicate if changes were made. The images or other third party material in this article are included in the article's Creative Commons licence, unless indicated otherwise in a credit line to the material. If material is not included in the article's Creative Commons licence and your intended use is not permitted by statutory regulation or exceeds the permitted use, you will need to obtain permission directly from the copyright holder. To view a copy of this licence, visit http://creativecommons.org/licenses/by/4.0/. 


\section{Introduction}

South Africa ranks among the top nations globally to spend a large amount of her national resources on education with respect to percentage gross domestic product (GDP) (Van der Berg \& Burger, 2003). Practically, government and stakeholders in Science, Technology, Engineering, and Mathematics (STEM) education try to grow sustainable decisions in STEM among students through the provision of funding from the National Student Financial Aid Scheme (NSFAS) and other supportive initiatives (Manuel, 2019). The NSFAS funding, through a ring-fenced system, provided for learning materials, tuition, and subsistence for beneficiaries. However, a recent change in its ring-fenced policy to outright cash transfers to beneficiary accounts seems to have resulted in a notable drop in the rate of textbook purchase and decline in academic performance by students. A non-profit organisation called the Alliance for Academic Success cautions that most beneficiaries of the monetary disbursements are using the funds to address family challenges instead of their academic needs (Duma, 2019).

Unfortunately, South Africa was among the four lowest performing nations in STEM at the tertiary level in sub-Saharan Africa between 2011 and 2015 (Tikly et al., 2018), with "only 1 in 10" high school learners deciding to pursue a career in STEM at tertiary level (Planet Earth Institute, 2016). Furthermore, high attrition and low performance among enrolled STEM students is frequently documented (Prince, 2017). Therefore, additional high school and university programmes have been developed to further motivate students to choose STEM courses (Kirby \& Dempster, 2018; Tikly et al., 2018). Although some of these endeavours have been helpful, career decision-making still poses challenges among students (Fogarty \& McGregor-Bayne, 2008).

\section{Literature review}

Global literature is rich in empirical evidence about the factors influencing career decision-making, some of which are family influence, passion, capacity, self-efficacy, apparent difficulty, values, sense of belonging, gender and race (Bieri Buschor, Berweger, Keck Frei, \& Kappler, 2014; Lent et al., 2005; Rainey, Dancy, Mickelson, Stearns, \& Moller, 2018; Rainey, Dancy, Mickelson, Stearns, \& Moller, 2019). The bulk of attention for the past two decades has been on investigating career decision-making in STEM in western countries. However, there is potential in examining how the phenomenon is experienced in the South African context.

Career decision-making comprises several domains and complex processes. Gelatt's (1962) progressive decision-making model offers a supporting foundation for comprehending how career decisions are made. The model shows the process of decision-making as an ongoing activity that changes dynamically with the acquisition of additional information. For instance, a young learner who is exposed to technological tools used by their father could learn how to use them and decide over time to choose a career in technology. Furthering the view of Gelatt (1962), Niles, Amundson, and Neault (2010) propose that adolescents are pre-emptive catalysts of the socio-cultural domain. Hence, they dynamically integrate knowledge and texts from others to ultimately develop a repository of decision-making.

Outcome expectancy is one of the major constructs that inform career decision-making. It involves the perceived outcomes of performing specific actions (i.e., "if I do this, what will happen?"). The construct assesses young people's perceptions of several professions based on their apparent economic, shared, and self-satisfaction outcomes. In established frameworks such as the social cognitive career theory (SCCT), career outcome expectancy is positioned as a key mediator of profession and scholarly interest and skill development (Nugent et al., 2015). In addition, there are empirical proofs that outcome expectancy, career interest, and self-efficacy are influential in predicting intentions to pursue a career (Blotnicky, Franz-Odendaal, French, \& Joy, 2018; Fouad \& Smith, 1996).

Another construct, career interest, is a predictor of both career preference and outcome (Nugent et al., 2015). Scholars found that career interest is positively connected to decisions to enrol in a field (Hulleman, Durik, Schweigert, \& Harackiewicz, 2008). Students who show interests in STEM early in life often decide to study STEM ultimately (OECD, 2005).

Furthermore, self-efficacy has been examined as a predictor of career interest using SCCT theories (Fouad \& Smith, 1996; Lent, Brown, \& Hackett, 1994). Personal factors and practical STEM-related behaviors influence the formation of self-efficacy, interests, and values, which impact decisions in STEM (Jacobs, Davis-Kean, Bleeker, Eccles, \& Malanchuk, 2005; Tate et al., 2015). Eccles and her associates propose that educators, peers, and families are well positioned to create prospects for students to participate in several STEM-associated activities via learning experiences and special courses (Eccles, Wigfield, \& Schiefele, 1997; Wang \& Eccles, 2012).

Additionally, the decision to pursue a career in STEM associates with parental influence. Mzobe (2014) confirmed that in a study conducted in South Africa, the role played by family in the career decision of students was more significant than monetary influences. Furthermore, Bandura (1977) asserts that families, educators, and peers are vitally influential in the enhancement of self-efficacy beliefs. Studies have established that selfefficacy could be developed when families and educators 
accentuate the significance and worth of career proficiencies (Bandura, Barbaranelli, Caprara, \& Pastorelli, 2001). The influence of family support and attitudes to STEM have been operationalized in several ways, for example, the development of SCCT to incorporate socialcontextual factors (Lent, Lopez Jr, Lopez, \& Sheu, 2008). Workman (2015) confirms that parental influence was dominant among the themes in learner decision-making processes. This claim is confirmed by several other scholars (Nugent et al., 2015). Jacobs, Chhin, and Bleeker (2006) report that the girl learner's self-perceptions and proficiencies were influenced by parental gender labelling and encouraged gender-typed career choices. This could be responsible for the under participation of the female gender in STEM as reported globally (Hartung, Porfeli, \& Vondracek, 2005; Tikly et al., 2018; Wang \& Degol, 2017).

Studies have shown that educators have a strong influence on learner decision-making (Clotfelter, Ladd, \& Vigdor, 2007; Rivkin, Hanushek, \& Kain, 2005). Likewise, the attitudes of students' peers, their accomplishments, and standards can wield a sharp influence on young people's interest in choosing and deciding to study a specific course (Olitsky, Flohr, Gardner, \& Billups, 2010). The period of growing up is a time of acquiring a personality and sense of self, and during this period peers can be very instrumental in guiding each other's choices, behaviors, and career interests (Vedder-Weiss \& Fortus, 2013).

The role of personality in career decision-making behavior is well researched (Holland, 1997, 1959; Seibert and Kraimer, 2001; Sullivan \& Hansen, 2004). Holland (1959) proposed a theory suggesting that an individual's career interest expresses their personality. The theory suggested that personality is a combination of several factors comprising capabilities, interests, behaviors, and principles.

The overarching aim of the present study was to explore the career decision-making of STEM students in a South African university to understand the students' perspectives about the factors that significantly influenced their decision to study STEM. This qualitative research explored the influential factors in the career decision-making of the participants. The research integrated a hermeneutic phenomenological method to traditional content analysis. Since the study is exploratory in nature, attention was given to describing the different range of students' viewpoints and experiences. Several students reported, among other factors, that their families, personality, and expectations played influential roles in their career decision-making. Thus, this paper presents the meaning of interpersonal, intrapersonal, and outcome expectations with respect to career decision-making for STEM students in a South African university. With better insight into students' perspectives on career decision-making, educators can better educate students about their chosen field.

\section{Research question}

The investigators explored what students perceived influenced their career decision-making within the intricate context of STEM education settings in a university in South Africa. The aim was to uncover influential factors entrenched in students' decision-making. The investigators sought to interpret students' career decisionmaking journeys and experiences. The term "career decision-making journey" is used here to describe students' education experiences and the circumstances, individuals, and actions that impacted on their career decision-making. The major question of this study was what defining situation, event, or individual helped STEM students to make the decision to pursue a career in STEM? The question contains many entrenched and intersecting occurrences needing obvious consideration to comprehend and interpret the key phenomenon of this research.

\section{Methodology \\ Conceptual approach}

Hermeneutic phenomenology proposed by Martin Heidegger (1889-1976) (Laverty, 2003), tries to discover the "essence" of people's lived encounters with phenomena and the factors that influence those encounters (Bynum \& Varpio, 2018; Creswell \& Poth, 2016). The technique reflects other people's encounters and considerations to explain the deeper meaning of phenomena (Bynum \& Varpio, 2018). Through the examination of people who went through an experience, researchers acquire greater understanding of factors that influence the wider context of STEM education. This method was selected partly because the topic of this research, "exploring the factors that influence the career decision of STEM students at a university in South Africa," was of personal interest to the researchers who had themselves experienced career decision-making challenges (Bynum \& Varpio, 2018).

Hermeneutic analysis additionally permits investigators to explore factors that are "taken for granted" (Bynum \& Varpio, 2018), like those reported in several prior studies (Bennett \& Phillips, 2010; Clinite et al., 2014; Grayson, Newton, \& Thompson, 2012; Klingensmith et al., 2015; Phillips, Peterson, Fang, Kovar-Gough, \& Phillips Jr, 2019a), that learners and residents in the medical profession are motivated by earnings and debts in their career decision-making process. By using a hermeneutic approach, investigators recognise contextual effects of participants' encounters that ordinarily couch beneath, undetected (Bynum \& Varpio, 2018). In line with Bennett and Phillips' model (Bennett \& Phillips, 2010) which accentuates that learners experience career 
preparation in diverse manners, this study focuses on the array of students' lived experiences as they made their career decisions.

\section{Setting}

This qualitative research was conducted on one campus of the largest university in the province of KwaZuluNatal. Study participants were enlisted from undergraduate students in Science, Technology, Engineering, and Mathematics (STEM) at the university investigated in 2019, and they were in their 1st, 2nd, 3rd, and 4th year of study, respectively.

\section{Data collection and participants}

Within the viewpoint supporting hermeneutic phenomenology, investigators need to create a research approach that runs directly from the research question and aims of the study. Questions in a semi-structured format (see Additional file 1) were designed to determine the factors that influenced STEM students' career decision-making at the university in South Africa (see Additional file 1). According to the reports of Phillips, Wilbanks, Rodriguez-Salinas, and Doberneck (2019b), data gathering using written texts (essays) permits many learners to participate in the research, answering in their own words. In line with Phillips et al. (2019a), six semistructured questions to uncover factors affecting STEM students' career decision-making were crafted. Participants were expected to respond to all six questions instead of one to generate meaningful data. The questions were piloted with a group of students who were not among the participating fields for clarity. Thereafter, the questionnaire was published on the university's website for participants to access and complete. Consent forms for each participant were also posted online.

Based on Krejcie and Morgan's (1970) table for determining sample size, from a target population of 2000 undergraduate STEM students, a sample of 322 was selected. Out of the sample of 322 STEM students, a total of 203 (63\% response rate) responded to the questionnaire. Data was collected over a six-month period. However, the purposeful sampling technique (Patton, 2002) was further used to select 150 responses out of the 203 total responses when saturation occurred.

Saturation happens at the point where "additional data does not lead to any new emergent themes" (Given, 2015, p. 134). In this study, although a hermeneutic phenomenological analysis was adopted, saturation occurred more across than inside individual cases, owing to the large number of participants who participated. Scholars suggest that saturation's importance and meaning are variously attributed by researchers contingent upon theoretical role and analytical approach used; hence, it could serve dissimilar purposes for various types of studies (Saunders et al., 2018). In this context, saturation in this study was interpreted as the point where the researchers found that the responses from participants seemed to be revolving around the captured themes and no more significantly new information could be derived from the remaining collected data.

This research was appraised and approved by the ethics committee of the university as a part of the postdoctoral study funded by the National Research Foundation and the Department of Science and Technology.

\section{Data analysis}

The research team included a Ph.D. student (Nneka Akwu) in Sciences, a professional data analyst (Idris Ganiyu) who also holds a Ph.D. in management studies, an education professor (Vitallis Chikoko), and a leadership expert (Isaac I. Abe) also holding a Ph.D. in leadership studies. Since this study was designed as an exploratory one, the responses were analyzed qualitatively through a hermeneutic phenomenological method to typical content analysis, with themes developing inductively from the collected data (instead of by a prearranged, concept-driven coding system) (Crabtree \& Miller, 1999; Hsieh \& Shannon, 2005). This method permitted themes and their descriptions to proceed from the data (Hsieh \& Shannon, 2005), which is vital in exploratory research. Since the data source for this study was a voluminous text pool from many participants instead of in-depth interviews, the researchers could not ask follow-up queries or investigate the vital concepts further. Hence, the analysis fused several student opinions and concepts into developing themes instead of trying to broadly depict each student's personal experiences and opinions.

Attention was given to describing the different groups of participants' lived experiences, focusing on minority views. Regardless of the limitations associated with the static data source, a large quantity of data permits for a comprehensive exploration of participants' viewpoints about career decision-making. The scholars primarily immersed themselves in the collected information by reading the texts repetitively to create meaning out of the entire data (Crabtree \& Miller, 1999; Hsieh \& Shannon, 2005). Preliminary codes were generated from repeated readings of individual texts and documented in a comprehensive codebook. Through a continuous comparative procedure, commonalities and divergences were refined and documented in the codebook.

Each participant's submitted text was subsequently separately coded by a minimum of two members of the team, and their coding choices were assessed, and differences fixed in frequent study team meetings. Final coding was posted into QSR NVivo version 12 and the codes were then categorized into meaningful nascent 
themes (Miles \& Huberman, 1994; Ys, 1985). All through the analytical process, the scholars reflected on the way each data point (coded reports in texts) furthered the whole (developing themes), i.e., the "hermeneutic cycle" (Bynum \& Varpio, 2018; Creswell \& Poth, 2016). Explanations of each coded statement were equally scrutinised carefully by reverting to source texts and appraising them totally to confirm that the individual explanation matches the context of an individual participant's story.

The use of QSR NVivo software permitted the scholars to confirm that each code and developing theme were backed by the text. Text coding and careful examination of codes and themes were sustained until data saturation was arrived at no novel themes emerged (Miles \& Huberman, 1994; Ys, 1985). The scholars concentrated principally on the subject matter of interest: the factors that influence the career decision-making of STEM students (Bynum \& Varpio, 2018, Creswell \& Poth, 2016). Nevertheless in the procedure of examining these phenomena, factors linked to students' career decisionmaking emerged. Additionally, although the participants had created a lot of texts about several factors, they were silent about peer influence, although it was mentioned in the semi-structured questionnaire. Therefore, the research team agreed not to explore this topic in the study although literature is rich with studies on its influence on students' career decision-making (Wang \& Eccles, 2012; Eccles et al., 1997; Olitsky et al., 2010; VedderWeiss \& Fortus, 2013), acknowledging that since peer influence was directly mentioned in the primary research questionnaire, the exploration of peer influence in this study should be preliminary instead of thorough.

This study ensured that various approaches to confirm quality and rigour were applied (Anfara Jr, Brown, \& Mangione, 2002; Crabtree \& Miller, 1999). To confirm credibility, the sciences student brought clarity on students' ethos as a form of peer examination at every phase of the analytical process. Her viewpoint assisted to explain nuances in student feelings, particularly when the codebooks were being refined. When the analysis was completed, developing themes were presented to a group of postgraduate STEM students and they corroborated that the themes echoed their experiences. Since these students did not participate in the study, this step was a revised type of member checking. The investigators added explicit inclusion and exclusion code standards and findings were conveyed by using deep, rich narrative to strengthen transferability. To confirm dependability, the study team applied the code-recode principle and used QSR NVivo version 12 to create an appraisal path (Anfara Jr et al., 2002).

Lastly, hermeneutic phenomenology demands that investigators acknowledge their previous encounters as "embedded in and essential to the analysis process" (Bynum \& Varpio, 2018). The investigators followed reflexivity by disclosing, pondering on, and listening to their experiences and ideas. Researchers talked about their individual responses to the data all through the investigation process. The study team often scrutinised and inspected their emerging explanations of the texts as a group and urged honest discussion about conflicting or divergent interpretations. These processes were adopted to confirm the researchers' experiences in education leadership, management, data analysis, sciences, and leadership, and to ensure other uncharted preconceptions did not influence the quality of the analytical process and findings.

\section{Results}

Three key themes about STEM students' career decision-making emerged from the analysis, namely interpersonal factors, intrapersonal factors, and career outcomes expectancy. Interpersonal factors are of varying types and have numerous levels of importance to different students. Intrapersonal factors resonated with many students and they reported a variety of reasons including career interest, personality, and self-efficacy as very influential in their career decision-making. Finally, students also stated that career outcomes expectancy was relevant to their career decision-making. The results are summarised in Table 1. Below is a presentation of the key themes and sub-themes that emerged from this study.

\section{Key theme 1: interpersonal influences}

STEM students who participated in this study generally considered interpersonal influence, but in describing the family, they reported different levels of family influence on their decision-making. Some students wrote that family was of no influence at all in their decision to study STEM.

\section{Family influence}

The key finding common to all (100\%) participating students in the study was family influence. The phenomenon was embedded in specific situations and in the context of decision-making. They reasoned that they made their best career decisions when around their families or in their learning environment. The students' perceptions of their families' influence on their decision to study STEM are summarily described as: "very influential," "somehow influential," "no influence," and "family needs my support." The responses captured under the "no-influence" subcategory was further grouped into "career prejudice" and "left alone to decide." The use of these adjectives does not in any way carry measurable 
Table 1 STEM Students' description of the factors underlying their career decision-making

\begin{tabular}{|c|c|c|c|}
\hline Key findings & $\begin{array}{l}\text { Student } \\
\text { numbers } 150\end{array}$ & Themes & Description of outcomes \\
\hline \multirow[t]{6}{*}{$\begin{array}{l}\text { Interpersonal } \\
\text { influence }\end{array}$} & 150 & $\begin{array}{l}\text { Family is of varying } \\
\text { influence }\end{array}$ & $\begin{array}{l}\text { The students' perception of their families' influence on their decision to } \\
\text { study STEM are summarily described as "very influential," "somehow } \\
\text { influential," "no influence," and "family needs my support" }\end{array}$ \\
\hline & 68 & Family is very influential & $\begin{array}{l}\text { Among this category were } 68 \text { students representing } 45.33 \% \text { of the } \\
\text { participants }\end{array}$ \\
\hline & 40 & $\begin{array}{l}\text { Family is somehow } \\
\text { influential }\end{array}$ & 40 students (27\%) reported on this sub-theme. \\
\hline & 23 & Family has no influence & $\begin{array}{l}23 \text { students }(15.33 \%) \text { reported that their families were not influential in } \\
\text { their career decision-making. }\end{array}$ \\
\hline & 19 & Family needs my support & Few students numbering 19 (13\%) believed their families needed their support. \\
\hline & 30 & Teacher Influence & $\begin{array}{l}30 \text { students (20\%) reported that their teacher's input was influential in their } \\
\text { decision to choose a career in the STEM field. }\end{array}$ \\
\hline \multirow{6}{*}{$\begin{array}{l}\text { Intra-personal } \\
\text { influence }\end{array}$} & 45 & "Champion" mentality & Students numbering 45 (30\%) responded in line with this category. \\
\hline & 83 & Career interest in STEM & $\begin{array}{l}83 \text { students ( } 55.33 \%) \text { indicated that their decision to pursue a career in STEM } \\
\text { was based on interest. }\end{array}$ \\
\hline & 53 & Personality & $\begin{array}{l}\text { A total number of } 53 \text { students (35.33\%) attributed personality as being influential } \\
\text { in their decision to pursue a career in STEM. }\end{array}$ \\
\hline & 17 & Personal development & $\begin{array}{l}\text { A small number of students (17) representing } 11.33 \% \text { stated that personal } \\
\text { development needs contributed to their choice of s career in STEM }\end{array}$ \\
\hline & 57 & Self-efficacy & $\begin{array}{l}38 \%(57) \text { students reported that their self-efficacy convictions were influential in } \\
\text { their decision to pursue a career in STEM. }\end{array}$ \\
\hline & 21 & $\begin{array}{l}\text { Spirituality and } \\
\text { morality }\end{array}$ & $\begin{array}{l}21 \text { students (14\%) of the respondents believe that they were influenced by their } \\
\text { spiritual life to pursue a career in STEM. }\end{array}$ \\
\hline \multirow[t]{2}{*}{$\begin{array}{l}\text { Career outcomes } \\
\text { expectancy }\end{array}$} & 64 & Financial matters & $\begin{array}{l}\text { Approximately } 43 \% \text { (64) participants reported that financial matters influenced their } \\
\text { decision to follow a career in STEM. }\end{array}$ \\
\hline & 43 & $\begin{array}{l}\text { Career opportunities } \\
\text { and prospects }\end{array}$ & $\begin{array}{l}43 \text { students (29\%) believed that career opportunities and prospects attributable } \\
\text { to STEM influenced their choice of career in the area. }\end{array}$ \\
\hline
\end{tabular}

This is a summary of the coding scheme used for career decision-making explanations as found in the present study

significance but explains the meaning of the content derived from participants' responses.

Sixty-eight (45.33\%) students felt that their families were very influential in their decision to pursue a career in STEM, and they stated inter alia:

"My family has a huge positive influence because in my family they've advised me that in the field of STEM there are a lot of good opportunities as well as life itself as we use technology in our daily basis."

"My family encouraged me to enrol for STEM and has supported me $100 \%$ in my study choices and I personally enjoy STEM related fields, this has pushed me to achieve great academic success."

"My family influenced me a lot, everyone in the family believes in STEM, I also think STEM is the future."

"My family has shown me what to expect in different STEM fields. They also showed me what careers might be good for my personality."
"My current career was greatly influenced by the fact that my late uncle used to hire me to work with him part time on his Engineering related business."

"They have a great influence, they even told how it is going to benefit me when I am done studying and how great it is."

However, 40 other students, representing $27 \%$ of the respondents, believed that their families were somehow influential; however, the final decision to study STEM was made by them. These students felt that their families played supportive roles in their decision to pursue STEM careers. There were innuendos suggestive that some students made their decision without family interference or that the family suggested a course different from the learner's choice but subsequently agreed to support the student's decision. These participants reported as follows:

"My family has been somewhat influential in me having a career and being independent. I am very determined to change my way lifestyle, therefore am willing to work hard in my chosen field." 
"I have reached a point where my family is much caring about pursuing my chosen field, they encourage me not to give up but try to tolerate every situation comes across to fulfil my potential desires."

"I'm the only one who have a qualification at home, I get more encouragement to study from them. I was raised by a farm worker so pursuing studies under STEM is something I grew up wishing although less support from them because they are not educated."

Yet, a worrisome sub-theme emerged where some students felt that they were under obligation to support their family. This trend could be referred to as an inverse influence on students' decision to study STEM. The responses of the 19 (13\%) participants who submitted the comments in the sub-theme family needs my support are as follows:

"I tend to take career decisions based on how urgent my family needs support. it hasn't paid off so far, but it does have an impact on my decision making."

"They are very happy because they know that by being under STEM may lead to many job opportunities to help."

"My family just wants me to have a career that will guarantee a good lifestyle at the end. When you are born under privileged, you are not satisfied by life. Hence, you always believe you must be successful at what you do, even if it is a career within STEM to support the family."

Conversely, 23 students (15.33\%) were convinced that their families made no contribution to their decision to study STEM. Although it seems these participants' families did not have had any influence on their decision, none of the participants came across as predominantly worried by the lack of family influence; it just did not appear to be a huge factor in their lives, since they reasoned that poor or lack of education for instance, contributed to their non-contributory influence. Further understanding of the intricacies of family influence in the career decision-making behavior of STEM students in this university could yield meaningful results. However, the reports deduced from the texts of participants who reported that their family had no influence over their career decision, therefore, they were left alone to decide are

"My parents are not educated, so they supported and appreciated that I wanted to continue studying after Grade 12; as to what field I chose they had no influence at all."

"My family has no influence whatsoever on my decision to study STEM."

"My family doesn't contribute that much in my life, so I make all the decisions by myself."

"My family pretty much doesn't care about what I do, as long as I'm studying."

"My family they do not care what studies I take the only thing they want is to see me happy in what I do and study."

"My family doesn't affect that much about making decisions I only have a say to what I want to learn, and I should be the one knowing about the outcomes of my learning."

"My family members are mostly uneducated therefore my decision will not be influenced with anything that they may want to say."

Additionally, career prejudice emerged as one of the reasons explicating why the family had no influence on the decision-making behavior of participating students that said:

"They (family) sometimes have prejudice about my career because of my gender."

"STEM includes my area of academic learning. I am studying Engineering. My family believes that if you choose a career in STEM, you might never finish your studies because it is difficult."

These students believed that their families were prejudiced against their decision to follow a career in STEM.

\section{Teacher influence}

This second category of theme one (interpersonal influence) showcases the influence that teachers have on the career decision-making behavior of STEM students. The $30(20 \%)$ participants who acknowledged the significant role of their teachers in their career decision-making reported as follows:

"Well during my high school days I taught myself but influence from my teacher made me more interested in STEM As for family they had no idea what I'm doing, all they wanted was me to be successful and that all."

"To a good extent, choosing a science stream as advised by my teacher in high school propelled me to do science related careers which I enjoy the most." 


\section{Key theme 2: intrapersonal influences}

Mzobe (2014) agrees with Young and Collin (2004) that there is an intrapersonal level of influence on career decisions. This level depicts the interface of self in the decision-making process of the individual student. The sub-themes here include the following:

\section{"Champion" mentality}

The first category under theme two is what is titled "champion" mind set. Individuals with champion mentality often want to "save" or "change" the world. The word was merely chosen to summarily capture the content of the responses of the $45(30 \%)$ participants in this category:

"STEM is most effective way in fast development of our country, since we need more people in STEM related field in South Africa to quickly grow our economy and have a much broad experience in our own to benefit the country and the world at large, I decided to choose a career in STEM."

"In my family, we've never had an Engineer, so If complete my studies, I'll be the first engineer in my family and surely I will make a difference and my family will be really proud."

"Engineering seemed like a fun major and that it can lead to great things by helping people."

"To become one of the scientists in the world and be able to improve the living of people in the world using different skills in science."

"My family and personal traits influenced me a lot as in the world we are living in families are viewed as inferior or people who won't do science, so I wanted to prove to the world that I can."

Commonly participants whose responses are documented in this category desire to make a difference in their family and/or society. They strongly believe that by pursuing a career in STEM they would be changing their family's status or helping society at large.

\section{Career interest in STEM}

This is the second category under theme two. Interestingly, 83 students $(55.33 \%)$ stated that the decision to pursue a career in STEM was based on their career interest. These participants' passion, dreams, aspirations, desire, and curiosity to study a career in STEM were highlighted in their responses. Career interest is important in the decision-making process of students and has implication for policy decisions. Participants' statements include the following:

"My personal interest in this career influenced my decision to study STEM to a great extent."

"I'm passionate about the field of science."

"I've always loved science, especially biology. My parents always encouraged me to pursue a career I am passionate about."

"Passion and curiosity for the environment attracted me to science."

"I have always been curious and enjoyed STEM."

"I have always loved nature and what makes it, hence i have always enjoyed biology."

"My decision to study STEM was influenced more by my own interests and my traits than my family."

"I've always had a passion for helping other people and a fascination for the human body and this influenced my decision to choose a degree in health sciences."

"I am interested in evolving things, research and innovations. This encouraged me towards STEM field."

\section{Personality}

This is the third category of factors influencing career decision-making as found in theme two. This term is used purely as a descriptive presentation of interpretations of individual student's personality, reasoning, or aptitude deduced from their feedback. Fifty-three (35.33\%) participants identified their personality as being influential in their decision-making behavior. Their comments are as follows:

"No one other than myself who has the say in my life influences and to what I decide on doing."

"It's certainly only personal traits that influenced my career choice and decision."

"My inquisitive approach to life at large and my family supportive nature on supporting my journey in obtaining such information."

"Individual traits: my (particular sort of) intelligence and manner of thinking resulted in an affinity for mathematics and physics." 
"I am a very logical thinker and naturally very curious. These traits lead me to study STEM and makes learning easier as I am interested in what I'm learning." "I think my critical reasoning skills are the pain driver towards STEM."

\section{Personal development}

The fourth category of factors identified in theme two is personal development. Participants' desire to develop themselves with knowledge and skills attributed to STEM fields underpinned their decision to pursue a career in STEM. The 17 students $(11.33 \%)$ that responded in this category thought that a career in STEM would challenge and develop their potentials.

"STEM is incorporated in our everyday lives, pouring a litre of milk, baking a cake to sell to make a living, providing electricity for households. It is nice to know what goes on in the smaller parts of life which become the greater ones. I love learning about all that to improve the lives of others and mine." "To keep myself updated with new and incoming technology."

"I like to be challenged so that's why I choose a course in STEM which is a challenging course to bring out my potential."

\section{Self-efficacy}

This is the fifth category of concepts under theme two. Self-efficacy is the confident belief in one's self about one's ability to achieve goals and it develops from earlier experiences and verbal persuasions attributable to the environment of upbringing. In this study, 38\% (57) of the participants appeared to believe that they could be successful in a career in STEM. They seemed to understand what they could do as stated below:

"I believe in me. Being in harmony with my family and with myself, I've known to accept my strengths and weaknesses and through assessing those, I know I wouldn't want to study anything else. And accepting that I'm studying what I believe I was born to do, makes me appreciate more and work harder."

"Family satisfaction makes for a motivating environment which allows me to grow and believe in myself during my studying journey."

"My family believes in me, I believe and know that I can succeed in almost everything that I set my mind into, which is why I went to science even though it wasn't my first or even second option. I'm doing well my results are good."

\section{Spirituality}

This is the sixth concept in the category of factors found in theme two. Participants seemed to believe that they were influenced by their spiritual life to pursue a career in STEM. Others saw morality and values as being supreme to financial benefits deriving from a successful completion of study in STEM. These 21 (14\%) participants said:

"I pray about all my decisions and entrust them to Jesus."

"Being in the STEM requires one to be in tune with their moral and spiritual values more than financial needs."

\section{Theme 3: career outcomes expectancy}

Career outcomes expectancy expresses young people's perception of some careers based on their apparent financial, societal, and self-satisfaction outcomes. Subthemes that emerged here are as follows:

\section{Financial matters}

Financial matters describe the first category of factors that emerged in theme three. This study did not set out to evaluate the effect of finance on career decisionmaking behavior of students in STEM, but it emerged as a theme. However, 64 (43\%) students appeared to perceive a career in STEM as economically very rewarding. Therefore, the expectation of better pay when studies are completed could have stimulated their decision to pursue a career in STEM. Participants' statements are as follows:

"It's a good career path and it's paying well since it's a scarce skill."

"I chose my career according to my ability and interests and future financial stability."

"Finance greatly affected my learning decision, especially family related issues that demanded financial contribution."

"I wanna be happy in what I do and be glad of my finances being able to help and support my parents in every way possible for me, so I'd be happy."

\section{Career opportunities and prospects}

These factors emerged as the second category of theme three. Forty-three students (29\%) who participated in this study felt that families understood the benefits and 
prospects of pursuing a career in STEM. Their comments are stated below:

"My family believes Science has more opportunities, benefits and career prospects more than other fields of study."

"STEM there are lots of job opportunities and you can get a job. Some of the jobs are similar and you can use skills from one job in the other job."

"My family had always told me about the opportunities that sciences provided, the money and also the respect for STEM learners."

\section{Discussion}

This qualitative research provides insight and perspective into the factors that influenced the career decisions of participating STEM students in a South African university.

\section{Interpersonal factors}

The finding in this study that the interpersonal relationships that students had formed with family, teachers, and peers are vital in relation to career decision-making is supported by Bennett and Phillips' (2010) model, which confirmed that in making their career decisions, students consider various values and experiences that impact individual decisions differently. For instance family and teacher influences were found to have had varying degrees of influence on participants' career decisionmaking in this study. This result is also supported by previous evidence that showcases family influence as a leading theme among the themes in career decisionmaking (Jacobs et al., 2006; Nugent et al., 2015; Workman, 2015).

Unlike prior studies on career development of students (Mzobe, 2014; Zahra \& Malik, 2017), using a qualitative approach, this study uniquely identified a dimensional angle to family influence on the phenomenon investigated. For several participants, family was found to be very influential in their career decision-making, as commonly reported by scholars (Mzobe, 2014; Nugent et al., 2015; Workman, 2015). However, it was interesting to find in this study that some participants distanced themselves from the family as an influential factor on their career decision-making. Those students firmly reported that other factors such as the need to support their family took greater priority in their career decision-making. Summarily, interpersonal factors were found to be the most prominent reason cited by participants for career decision-making in this study. This implies that educators and stakeholders who have an interest in closing the STEM skills gap by understanding how students make their decision to major in STEM can take note of the levels of influence that the family has on student career decision-making, create constructive initiatives, and offer structures that foster robust interpersonal connections in a productively strategic manner.

Although participants indicated that support received from their families influenced their decision to study STEM, the present study did not classify the form of support received. Further studies could unravel this relationship.

\section{Intrapersonal factors}

STEM students also cited champion mind set, career interest, personality, personal development, self-efficacy, spirituality, and morality, which were categorized as intrapersonal factors, to explain why they decided to pursue a study in the STEM field. This is an essential discovery to note because it agrees with the idea that interest, self-efficacy, and personality are influential in career decision-making (Tzu-Ling, 2019; Wu, Zhang, Zhou, \& Chen, 2020; Yu \& Jen, 2019), and implies that focus on individual cognitive factors in investigations on career decision-making is founded. However, champion mind set, spirituality, and morality also mentioned by participants as reasons for their career decisionmaking-even though cognitive factors have meaningful influence on career decision-making-is notable. This finding importantly implies that operational and cultural factors in addition to individual cognitive and interpersonal factors should be considered in future investigations of representation in STEM.

\section{Outcome expectancy}

An outcome expectancy as a construct measuring students' perception of some careers based on their perceived financial, societal, and self-satisfaction effects (Nugent et al., 2015) was confirmed to be influential in STEM student career decision-making in this study. Participating students expect to gain financial stability and independence by exploiting the career opportunities and prospects they foresee in the STEM fields. For the participants who place value on financial and economic expectations, the earnings could offer them the ability to meet the financial needs of their family members. The findings also clarify the understanding of the lens through which participants view the STEM field for opportunities and prospects. This characterisation of outcome expectancy is specifically useful because it could assist career counselors in supporting the students in defining their career pursuit in STEM.

Furthermore, the findings of the present study showed that in addition to outcomes expectancy; family, teachers, self-efficacy, interest, spirituality, morality, and personality, among other factors, are influential in 
students' decision to pursue a career in STEM. Several studies on career interest, career growth, self-efficacy, and career outcomes expectancy have been conducted among students in high schools and tertiary institutions. A study was conducted among university students in Spain to investigate the effect of perceived supports and hindrances to self-efficacy convictions and other socialcognitive variables associated with STEM students' career development (Peña-Calvo, Inda-Caro, RodríguezMenéndez, \& Fernández-García, 2016). While another study among Taiwanese college students investigated their career interests and career goals for majoring in STEM (Mau, Chen, \& Lin, 2020), Baglama and Uzunboylu (2017) examined the association between career decision-making self-efficacy and career outcomes expectancy among Turkish preservice teachers. They found that career decision-making self-efficacy significantly predicts career outcome expectancy.

However, STEM students need assistance in finding information concerning the world of work, transforming from students to professionals, planning for work, and coping with pressure (Güneri, Aydın, \& Skovholt, 2003). The transitioning process may not be easy on the students. A study conducted by Gizir (2005) among graduating university students found that they feel apprehensive about getting employed after graduation and are also uncertain about what the future holds for them. For this purpose, this study may be of valueadding benefit in describing the career counseling needs of STEM students. It could be implied then that knowing what to do post-graduation and the way to approach the world of work could make STEM undergraduates commit to their career.

A study carried out by Vertsberger and Gati (2016) discovered that adolescents facing career decision challenges and pessimistic outcomes expectancy concerning their potential careers are inclined to seek help in the process. This has a significantly important implication with regards to career counseling initiatives designed to assist students and heightens the cognisance of the value of offering support for students in their career decision-making process. Ascertaining the variables that influence career-associated opinions and behaviors of STEM students in tertiary institutions could result in the control of these variables and the learners being assisted. Because of the importance of providing career guidance and support, it could be inferred that the present study will add to the improvement of counseling interventions. In addition, numerous scholars have focused on student career decision processes elsewhere globally, it is therefore expected that the present study would offer a dissimilar cultural viewpoint to findings from SubSaharan Africa. Scholars from elsewhere globally, including the USA, China, Turkey, Taiwan, Spain, and other regions in Africa, would derive benefit from the results of this study.

\section{Conclusion}

STEM students approach their career decision-making from diverse perspectives and experiences. Likewise, they appraise the influence of interpersonal and intrapersonal factors to different levels and for a variety of reasons, and interestingly, the family emerged as a dominantly influential element among a host of others found in this study. By comprehending students' perspectives on career decision-making, STEM educators can assist students in making decisions that reflect their values and experiences.

\section{Limitations}

A few limitations should be acknowledged. This research was undertaken at a single tertiary institution. Learners at other institutions could have dissimilar opinions on interpersonal and intrapersonal factors and career outcomes expectation. Texts generated from undergraduate STEM students offered insights into their perceptions at that period; these ideas could change as career plans develop, for instance in postgraduate years. Participants wrote their responses in the context of semi-structured questions. Their answers could have been influenced by the desire to provide generally satisfactory information. As stated above, the data gathering method-the assessment of student texts-differs from the typical hermeneutic phenomenology approach, whereby data is gathered from people using in-depth interviews (Phillips et al., 2019a). The investigators had no chance to ask follow-up questions to make more enquiry into matters of interest as would have been done in a procedure involving interviews. Lastly, since the questionnaire did not ask participants to respond to financial issues and gender, the findings may not mirror the full range of participants' ideas of the effects of finances and gender on career decision-making. Further investigation is required to explore these constructs further to confirm the study's results as generalizable.

\section{Implications}

These findings involving interpersonal, intrapersonal, and career outcomes expectancy in the decision to pursue a career in STEM have important theoretical and practical implications. Firstly, this study, like several other studies, has yet again been supported using a phenomenological hermeneutic approach. However, the researchers are quick to agree that this finding is limited to the university investigated and the 
peculiarity of the environment, bearing in mind Holland's (1959) position. He was of the conviction that the experience that an individual acquires in the environment of his/her upbringing creates the inclination towards specific interests or behaviors that combine with the individual's values to shape their personality trait.

Secondly, this study invites awareness to the finding that although peer influence was prominent in extant literature as an influence on students' career decisionmaking (Eccles et al., 1997; Olitsky et al., 2010; Vedder-Weiss \& Fortus, 2013; Wang \& Eccles, 2012), the present study found a different result-peer influence was not notable. Further studies are recommended to explicate the reason behind this finding.

Interestingly, the need to support family was an unexpected sub-theme that emerged from family influence on career decision-making in this study. The students who reported that they needed to support their families were not very pointed about the way in which they needed to support their families and why. Further study would be needed to explore this phenomenon and could be meaningful in assisting educators and policymakers in making more informed decisions on how best to serve this category of STEM students. However, individuals interested in motivating students to pursue STEM careers could consider the fact that majority of the students affirmed that their family was influential in their career decisionmaking, while some other students considered it financially rewarding. These, in addition to the other factors identified in this study, could be taken into consideration and integrated into future STEM outreach and initiatives. The factors influencing students' career decision-making have implications for how institutional practices, educational caretakers, and stakeholders shape students' support.

\section{Supplementary Information}

Supplementary information accompanies this paper at https://doi.org/10. 1186/s40594-020-00256-X.

Additional file 1. Stem Study Semi-Structured Questionnaire.

\section{Abbreviations \\ NSFAS: National Student Financial Aid Scheme; SCCT: Social Cognitive Career Theory; Ph.D.: Doctor of Philosophy; QSR International: Technology \& Software Solutions, owners of NVivo software; STEM: Science, Technology, Engineering, and Mathematics}

\section{Acknowledgements}

Funding was provided to author by a grant from the National Research Foundation of South Africa. We are thankful to the individuals who helped our team with vetting the coding structure and proof-reading the manuscript. Dr. Isaac I. Abe and Dr. Idris Ganiyu made extensive contributions to data analysis and interpretation and reviewed the paper critically. Nneka Akwu made substantial contribution to the code-recode process bringing the viewpoint of student nuance into consideration in the process of data collection and analysis.

\section{Authors' contributions}

The lead investigator had oversight of the conception and design of the study, collection, analyzing, and interpretation of data, as well as drafting of the manuscript. The education professor, Vitallis Chikoko, supervised all contributions and chaired meetings for reviews of the coding and recoding, read the drafts of the manuscript, and made valuable input. All authors approved the corrections and the final manuscript for submission and are in agreement to be responsible for all facets of the work in confirming that queries concerning the accuracy and integrity of any aspect of the work are properly examined and resolved.

\section{Availability of data and materials}

University ethics approval does not include release of the raw information. Data was collected from the STEM students under the stringent condition of anonymity and cannot be shared. Please contact the corresponding author for more information.

\section{Ethics approval and consent to participate}

This approval was granted by the Humanities and Social Sciences Research Ethics Committee of University of KwaZulu-Natal, Westville-Durban, South Africa.

\section{Competing interests}

The authors confirm that they have no conflict of interests.

Received: 20 February 2020 Accepted: 26 October 2020

Published online: 01 December 2020

\section{References}

Anfara Jr., V. A., Brown, K. M., \& Mangione, T. L. (2002). Qualitative analysis on stage: Making the research process more public. Educational Researcher, 31(7), 28-38.

Baglama, B., \& Uzunboylu, H. (2017). The relationship between career decisionmaking self-efficacy and vocational outcome expectations of preservice special education teachers. South African Journal of Education, 37(4), 1-11.

Bandura, A. (1977). Social learning theory. Prentice-hall.

Bandura, A., Barbaranelli, C., Caprara, G. V., \& Pastorelli, C. (2001). Self-efficacy beliefs as shapers of children's aspirations and career trajectories. Child Development, 72(1), 187-206.

Bennett, K. L., \& Phillips, J. P. (2010). Finding, recruiting, and sustaining the future primary care physician workforce: a new theoretical model of specialty choice process. Academic Medicine, 85(10), S81-S88.

Bieri Buschor, C., Berweger, S., Keck Frei, A., \& Kappler, C. (2014). Majoring in STEM - What accounts for women's career decision making? A mixed method study. The Journal of Educational Research, 107(3), 167-176.

Blotnicky, K. A., Franz-Odendaal, T., French, F., \& Joy, P. (2018). A study of the correlation between STEM career knowledge, mathematics self-efficacy, career interests, and career activities on the likelihood of pursuing a STEM career among middle school students. International Journal of STEM Education, 5(1), 22

Bynum, W., \& Varpio, L. (2018). When I say... hermeneutic phenomenology. Medical Education, 52(3), 252-253.

Clinite, K. L., DeZee, K. J., Durning, S. J., Kogan, J. R., Blevins, T., Chou, C. L., .. Kazantsev, S. M. (2014). Lifestyle factors and primary care specialty selection: comparing 2012-2013 graduating and matriculating medical students' thoughts on specialty lifestyle. Academic Medicine, 89(11), 1483-1489.

Clotfelter, C. T., Ladd, H. F., \& Vigdor, J. L. (2007). How and why do teacher credentials matter for student achievement? (No. w12828). Cambridge: National Bureau of Economic Research.

Crabtree, B. F., \& Miller, W. L. (1999). Doing qualitative research. Thousand Oaks: Sage Publications.

Creswell, J. W., \& Poth, C. N. (2016). Qualitative inquiry and research design: Choosing among five approaches. Thousand Oaks: Sage Publications.

Duma, N. (2019). Academic group: Students using funding to support families. Eyewitness News Available at https://ewn.co.za/2019/10/02/academic-groupstudents-using-nsfas-funds-to-support-families-not-buy-books. 
Eccles, J. S., Wigfield, A., \& Schiefele, U. (1997). Motivation to succeed. In W. Damon, \& N. Eisenberg (Eds.), Handbook of Child Psychology, (pp. 1017-1095). New York: Wiley.

Fogarty, G. J., \& McGregor-Bayne, H. (2008). Factors that influence career decisionmaking among elite athletes. Australian Journal of Career Development, 17(3), 26-38.

Fouad, N. A., \& Smith, P. L. (1996). A test of a social cognitive model for middle school students: Math and science. Journal of Counseling Psychology, 43(3), 338-346.

Gelatt, H. B. (1962). Decision-making: A conceptual frame of reference for counselling. Journal of Counseling Psychology, 9(3), 240-245.

Given, L. M. (2015). 100 questions (and answers) about qualitative research. Thousand Oaks: Sage Publications.

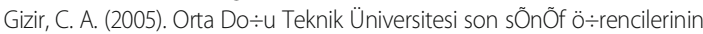
problemleri üzerine bir çalÕúma [A study on the problems of the Middle East Technical University senior students]. Mersin Üniversitesi E $\div$ itim Fakültesi Dergisi, 1(2), 196-213.

Grayson, M. S., Newton, D. A., \& Thompson, L. F. (2012). Payback time: the associations of debt and income with medical student career choice. Medical Education, 46(10), 983-991.

Güneri, O. Y., Aydın, G., \& Skovholt, T. (2003). Counseling needs of students and evaluation of counseling services at a large urban university in Turkey. International Journal for the Advancement of Counselling, 25(1), 53-63.

Hartung, P. J., Porfeli, E. J., \& Vondracek, F. W. (2005). Child vocational development: A review and reconsideration. Journal of Vocational Behavior 66(3), 385-419.

Holland, J. L. (1959). A theory of vocational choice. Journal of Counseling Psychology, 6(1), 35-45.

Holland, J. L. (1997). Making vocational choices: A theory of vocational personalities and work environments. Psychological Assessment Resources.

Hsieh, H. F., \& Shannon, S. E. (2005). Three approaches to qualitative content analysis. Qualitative Health Research, 15(9), 1277-1288.

Hulleman, C. S., Durik, A. M., Schweigert, S. B., \& Harackiewicz, J. M. (2008). Task values, achievement goals, and interest: An integrative analysis. Journal of Educational Psychology, 100(2), 398-416.

Jacobs, J. E., Chhin, C. S., \& Bleeker, M. M. (2006). Enduring links: Parents' expectations and their young adult children's gender-typed occupational choices. Educational Research and Evaluation, 12(4), 395-407.

Jacobs, J. E., Davis-Kean, P., Bleeker, M., Eccles, J. S., \& Malanchuk, O. (2005). I can but I don't want to. The impact of parents, interests, and activities on gender differences in math. In A. Gallagher, \& J. Kaufman (Eds.), Gender difference in mathematics, (pp. 246-263).

Kirby, N. F., \& Dempster, E. R. (2018). Alternative access to tertiary science study in South Africa: Dealing with 'disadvantage', student diversity, and discrepancies in graduate success. In C. I. Agosti, \& E. Bernat (Eds.), University pathway programs: Local responses within a growing global trend, (pp. 85-106). Cham: Springer.

Klingensmith, M. E., Cogbill, T. H., Luchette, F., Biester, T., Samonte, K., Jones, A., .. Malangoni, M. A. (2015). Factors influencing the decision of surgery residency graduates to pursue general surgery practice versus fellowship. Annals of Surgery, 262(3), 449-455

Krejcie, R. V., \& Morgan, D. W. (1970). Determining sample size for research activities. Educational and Psychological Measurement, 30(3), 607-610.

Laverty, S. M. (2003). Hermeneutic phenomenology and phenomenology: A comparison of historical and methodological considerations. International Journal of Qualitative Methods, 2(3), 21-35.

Lent, R. W., Brown, S. D., \& Hackett, G. (1994). Toward a unifying social cognitive theory of career and academic interest, choice, and performance. Journal of Vocational Behavior, 45(1), 79-122.

Lent, R. W., Brown, S. D., Sheu, H. B., Schmidt, J., Brenner, B. R., Gloster, C. S., ... Treistman, D. (2005). Social cognitive predictors of academic interests and goals in engineering: Utility for women and students at historically black universities. Journal of Counseling Psychology, 52(1), 84-92.

Lent, R. W., Lopez Jr., A. M., Lopez, F. G., \& Sheu, H. B. (2008). Social cognitive career theory and the prediction of interests and choice goals in the computing disciplines. Journal of Vocational Behavior, 73(1), 52-62.

Manuel, R. (2019). Ubuntu ethics and the National Student Financial Aid Scheme (Doctoral dissertation, Stellenbosch: Stellenbosch University).

Mau, W. C. J., Chen, S. J., \& Lin, C. C. (2020). Social cognitive factors of science, technology, engineering, and mathematics career interests. International
Journal for Educational and Vocational Guidance. https://doi.org/10.1007/ s10775-020-09427-2.

Miles, M. B., \& Huberman, A. M. (1994). Qualitative data analysis: An expanded sourcebook. Thousand Oaks: Sage Publications.

Mzobe, N. (2014). A qualitative exploration of the career narratives of six South African Black professionals (Doctoral dissertation). Durban: University of KwaZulu-Natal.

Niles, S. G., Amundson, N. E., \& Neault, R. A. (2010). Career flow: A hope-centred approach to career development. Boston: Pearson.

Nugent, G., Barker, B., Welch, G., Grandgenett, N., Wu, C., \& Nelson, C. (2015). A model of factors contributing to STEM learning and career orientation. International Journal of Science Education, 37(7), 1067-1088.

OECD (2005). Publishing, Organisation for Economic Co-operation and Development Staff, and Centre for Educational Research and Innovation. In Education at a Glance 2005: OECD Indicators. Organisation for Economic Cooperation and Development.

Olitsky, S., Flohr, L. L., Gardner, J., \& Billups, M. (2010). Coherence, contradiction, and the development of school science identities. Journal of Research in Science Teaching, 47(10), 1209-1228.

Patton, M. Q. (2002). Two decades of developments in qualitative inquiry: A personal, experiential perspective. Qualitative social work, 1(3), 261-283.

Peña-Calvo, J. V., Inda-Caro, M., Rodríguez-Menéndez, C., \& FernándezGarcía, C. M. (2016). Perceived supports and barriers for career development for second-year STEM students. Journal of Engineering Education, 105(2), 341-365.

Phillips, J. P., Peterson, L. E., Fang, B., Kovar-Gough, I., \& Phillips Jr., R. L. (2019a). Debt and the emerging physician workforce: The relationship between educational debt and family medicine residents' practice and fellowship intentions. Academic Medicine, 94(2), 267-273.

Phillips, J. P., Wilbanks, D. M., Rodriguez-Salinas, D. F., \& Doberneck, D. M. (2019b). Specialty income and career decision making: a qualitative study of medical student perceptions. Medical Education, 53(6), 593-604.

Planet Earth Institute. (2016). What is the scientific independence of Africa? Available at http://planetearthinstitute.org.uk/about-scientific-independence/

Prince, R. (2017). The relationship between school-leaving examinations and university entrance assessments: The case of the South African system. Journal of Education (University of KwaZulu-Natal), (70), 133-160.

Rainey, K., Dancy, M., Mickelson, R., Stearns, E., \& Moller, S. (2018). Race and gender differences in how sense of belonging influences decisions to major in STEM. International Journal of STEM Education, 5(1), 10. https://doi.org/10. 1186/s40594-018-0115-6.

Rainey, K., Dancy, M., Mickelson, R., Stearns, E., \& Moller, S. (2019). A descriptive study of race and gender differences in how instructional style and perceived professor care influence decisions to major in STEM. International Journal of STEM Education, 6(1), 1-13.

Rivkin, S. G., Hanushek, E. A., \& Kain, J. F. (2005). Teachers, schools, and academic achievement. Econometrica, 73(2), 417-458.

Saunders, B., Sim, J., Kingstone, T., Baker, S., Waterfield, J., Bartlam, B., ... Jinks, C. (2018). Saturation in qualitative research: exploring its conceptualization and operationalization. Quality \& Qantity, 52(4), 1893-1907.

Seibert, S. E., \& Kraimer, M. L. (2001). The five-factor model of personality and career success. Journal of vocational behavior, 58(1), 1-21.

Sullivan, B. A., \& Hansen, J. I. C. (2004). Mapping associations between interests and personality: toward a conceptual understanding of individual differences in vocational behavior. Journal of Counseling Psychology, 51(3), 287-298.

Tate, K. A., Fouad, N. A., Marks, L. R., Young, G., Guzman, E., \& Williams, E. G. (2015). Underrepresented first-generation, low-income college students' pursuit of a graduate education: Investigating the influence of selfefficacy, coping efficacy, and family influence. Journal of Career Assessment, 23(3), 427-441.

Tikly, L., Joubert, M., Barrett, A. M., Bainton, D., Cameron, L., \& Doyle, H. (2018). Supporting secondary school STEM education for sustainable development in Africa. Bristol Working Papers in Education.

Tzu-Ling, H. (2019). Gender differences in high-school learning experiences, motivation, self-efficacy, and career aspirations among Taiwanese STEM college students. International Journal of Science Education, 41(13), 1870-1884.

Van der Berg, S., \& Burger, R. (2003). Education and socio-economic differentials: A study of school performance in the Western Cape. Cape Town: University of Cape Town. 
Vedder-Weiss, D., \& Fortus, D. (2013). School, teacher, peers, and parents' goals emphases and adolescents' motivation to learn science in and out of school. Journal of Research in Science Teaching, 50(8), 952-988.

Vertsberger, D., \& Gati, I. (2016). Career decision-making difficulties and help-seeking among Israeli young adults. Journal of Career Development, 43(2), 145-159.

Wang, M. T., \& Degol, J. L. (2017). Gender gap in science, technology, engineering, and mathematics (STEM): Current knowledge, implications for practice, policy, and future directions. Educational Psychology Review, 29(1), 119-140.

Wang, M. T., \& Eccles, J. S. (2012). Social support matters: Longitudinal effects of social support on three dimensions of school engagement from middle to high school. Child Development, 83(3), 877-895.

Workman, J. L. (2015). Parental influence on exploratory students' college choice, major, and career decision making. College Student Journal, 49(1), 23-30

Wu, S., Zhang, K., Zhou, S., \& Chen, W. (2020). Personality and career decisionmaking self-efficacy of students from poor rural areas in China. Social Behavior and Personality: an international journal, 48(5), 1-18.

Young, R. A., \& Collin, A. (2004). Introduction: Constructivism and social constructionism in the career field. Journal of Vocational Behavior, 64(3), 373-388.

Ys, L. (1985). Guba EG. Naturalistic inquiry. Beverly Hills. Sage Publications.

Yu, H. P., \& Jen, E. (2019). The gender role and career self-efficacy of gifted girls in STEM areas. High Ability Studies, 1-17.

Zahra, S. T., \& Malik, A. A. (2017). Role of significant others on high school students subject/career selection: An exploratory study.

\section{Publisher's Note}

Springer Nature remains neutral with regard to jurisdictional claims in published maps and institutional affiliations.

\section{Submit your manuscript to a SpringerOpen ${ }^{\circ}$ journal and benefit from:}

- Convenient online submission

- Rigorous peer review

- Open access: articles freely available online

- High visibility within the field

- Retaining the copyright to your article

Submit your next manuscript at $\boldsymbol{\nabla}$ springeropen.com 